\title{
Enhanced Nematicidal Effect of Cowdung Soil Amendment by Neem (Azadirachta indica)
}

\author{
Ibrahim Buba Galadima, Hassan Mohammed Auwal*, Ismail Abubakar, Jacob Madu, \\ Paul Joseph \\ Department of Crop Protection, Faculty of Agriculture, University of Maiduguri, Maiduguri, Nigeria \\ Email: ${ }^{*}$ auwal@unimaid.edu.ng
}

Received 1 August 2015; accepted 18 August 2015; published 21 August 2015

Copyright (C) 2015 by authors and OALib.

This work is licensed under the Creative Commons Attribution International License (CC BY).

http://creativecommons.org/licenses/by/4.0/

(c) (†) Open Access

\section{Abstract}

Field experiment was conducted during the rainy season (summer) of 2014 to determine the effect of mixture cow dung of neem on population of root knot nematode infesting okra. A parcel of land highly endemic to population of root knot nematode was chosen for the experiment. Treatments include sole neem at $11.5 \mathrm{~g}$, sole cowdung at $100 \mathrm{~g}$ and mixture of cowdung and neem at 111.5 g were applied to individual crop stand in plots of size $2.0 \mathrm{M}$ by $2.0 \mathrm{M}$. Furadan, a chemical nematicide was applied as a standard check. Non amended plots in which no treatment was applied served as a control. Crop stands numbering 16 per plot were planted with okra. The experiment was carried out in randomized complete block design (RCBD) with three replications. Data were collected on nematodes population and plant growth parameters and subjected to analysis of variance (ANOVA) and means were separated using Fisher's least significant difference (LSD). Results obtained showed mixture of neem and cow dung produced 27.6 second stage juvenile which was the lowest population obtained, with a concomitant highest okra yield of yield of 2.4 tons/hectre (T/ha). Sole neem and cow dung suppressed nematodes population by 35.3 and 98.6 respectively with attendant okra yield of 1.9 and $1.4 \mathrm{~T} / \mathrm{ha}$ respectively. Amendment of soil with mixture of neem and cow dung substantially suppressed Meloidogyne spp. infesting okra and may provide practical control of root-knot nematodes as part of sustainable nematode management system.

\section{Keywords}

Meloidogyne spp., Okra, Organic Amendments, Plant Parasitic Nematodes, Sustainable Agriculture

Subject Areas: Agricultural Science, Plant Science

\footnotetext{
${ }^{*}$ Corresponding author.

How to cite this paper: Galadima, I.B., Auwal, H.M., Abubakar, I., Madu, J. and Joseph, P. (2015) Enhanced Nematicidal Effect of Cowdung Soil Amendment by Neem (Azadirachta indica). Open Access Library Journal, 2: e1779. 


\section{Introduction}

Okra (Abelmoschus esculentus), a very important crop in Africa and other tropical and subtropical areas of the world belongs to the family malvaceae. It is a nutritional significant crop as it contains $9.7 \%$ carbohydrate, $2.2 \%$ protein, $1 \%$ fibre, $0.2 \%$ fats and $0.9 \%$ ash, it also contains a considerable amount of minerals, protein and vitamins A, B and C [1]. Like most other crops in tropical and sub-tropical region of the world okra is host to many pest and diseases. It is infamous for its high susceptibility to southern root knot nematodes (Meloidogyne incognita) where nematodes infestation commonly causes very irregular growth, with reduction and/or delay in the crop's production [2]. In India, root knot nematodes are reported to suppress okra yield by 91\% [3]. In Nigeria, [4] reported that most of the damage causes by Meloidogyne hapla on okra plants occurs early during the formation of tap root. High densities of nematodes at planting (several hundred/100 $\mathrm{cm}^{3}$ soils) induced loss of weight of foliage and roots, severe galling of roots, extreme malformation of storage roots and total loss of the crop [5]. Use of synthetic chemical nematicides is the predominant method of nematodes population management. However, nematicides have been reported to have negative effect on the environment, man and bio-diversity. This necessitates the demand for environment friendly effective alternative control measure that is ecological sound and cost effective. Reductions in populations of plant parasitic nematodes in response to application of organic amendments have been reported in many studies. The natural product of plants, animals or microbial origin are vast source of bioactive substances which have been exploited only to a limited extend in the preparation of pesticide [6].

\section{Materials and Method}

The experiment was carried out at the Faculty of Agriculture Teaching and Research Farm, University of Maiduguri, Nigeria during the rainy season (summer) from July to September 2014. The area is located at latitude $13 \mathrm{~S}, 15 \mathrm{~N}$ and longitude13 $\mathrm{E}$ which lies in the semi-arid north east region in Nigeria. It is characterized by scanty and short rainy season of five month from June to October. The soil texture is sandy loam with 65\% sand, $18 \%$ silt and 17\% clay. A parcel of land highly endemic to population of root knot nematode and on which okra was grown for three consecutive seasons was chosen for the experiment. Plot of size $2.0 \mathrm{M} \times 2.0 \mathrm{M}$ separated by 1.0 M inter plot spacing were demarcated. The experimental design was randomized complete block designed (RCBD) with five treatments each replicated three times. Neem seed was obtained from neem plantation at University of Maiduguri, it was shelled and the kernel obtained was dried under a shade and grinded manually using pestle and mortar. Cow dung manure was obtained from Livestock unit of the Department of Animal Science, University of Maiduguri and processed by drying, pulverizing and removal of all unwanted materials. Digital weighing machine was used to measure the appropriate quantity of the materials for application to each crop stand and then packed in polythene bag. The measured treatments include sole neem at $11.5 \mathrm{~g}$, sole cow dung at $100 \mathrm{~g}$ and mixture of neem and cowdung at $111.5 \mathrm{~g}$. These were applied to crop stand as the experiment treatments. Okra seed (Clemson variety) is obtained from registered seed suppliers and planted at rate of one seed per crop stand. Prior to treatments application and crop sowing, $250 \mathrm{~cm}^{3}$ of soil was collected from each of the fifteen plots for initial nematodes population (Pi) analysis. The initial (before application of treatments)nematode population was determined by taking three core samples with a soil auger to a depth of $20 \mathrm{~cm}$ in a zig-zag pattern from each experimental plot, bulked and labeled. The soil samples collected from each plot was analyzed in the laboratory to determine the plant parasitic nematode population. The White-Head and Hemming method of nematode extraction was used.

Analysis of variance (ANOVA) was carried out with the data collected. The difference between treatments means was also calculated using the least significance difference (LSD) test at both 5\% level of probability.

\section{Results and Discussion}

Table 1 showed no significant $(p<0.05)$ differences in nematode population prior to application of the various treatments to experimental plots. Organic soil amendment namely sole neem, sole cow dung and mixture of neem and cow dung were applied to crop stand at the rate of $11.5 \mathrm{~g}, 100 \mathrm{~g}$ and $111.5 \mathrm{~g}$ respectively. For the purpose of comparison chemical nematicide (Furadan) was applied at the rate of $1.0 \mathrm{~g}$ per crop stand. All treatments except cowdung hindered significantly $(p<0.05)$ the increase in population parameters of Meloidogyne spp. infesting okra. Combination of neem and cow dung applied at rate of 111.5 g per crop stand produce the best suppression of 27.6 second stage juvenile (J2) population, followed by neem applied at 11.5 g that produce 
Table 1. Effect of sole neem, sole cowdung manure and combination of neem and cow dung on Meloidogyne spp. population infecting okra.

\begin{tabular}{cccccc}
\hline Treatment & $\begin{array}{c}\text { Quantity } \\
\text { (grams) }\end{array}$ & $\begin{array}{c}\text { Initial population } \\
\mathbf{( P i )}\end{array}$ & $\begin{array}{c}\text { Final population } \\
\text { (Pf) }\end{array}$ & $\begin{array}{c}\text { Reproduction factors } \\
\text { [Pf/Pi] }\end{array}$ & Gall index \\
\hline Neem & 11.5 & $155.3 \mathrm{a}$ & $35.3 \mathrm{ab}$ & 0.2 & $2.5 \mathrm{a}$ \\
Manure & 100 & $135.0 \mathrm{a}$ & $98.6 \mathrm{a}$ & $0.7 \mathrm{c}$ & $3.2 \mathrm{c}$ \\
N + M & 111.5 & $157.3 \mathrm{a}$ & $27.6 \mathrm{c}$ & $0.1 \mathrm{c}$ & $0.8 \mathrm{ab}$ \\
Chemical & 1.0 & $115.3 \mathrm{a}$ & $30.0 \mathrm{ab}$ & $0.3 \mathrm{a}$ & $1.33 \mathrm{ab}$ \\
Control & 0 & $129.3 \mathrm{a}$ & $71.6 \mathrm{~b}$ & $0.6 \mathrm{a}$ & $1.33 \mathrm{ab}$ \\
\hline
\end{tabular}

Values are mean of three replications. Means followed by same letter within each column are not significantly different $(P<0.05)$ according to Fisher's least significant different (LSD) test.

35.3, cowdung produce 98.6. The non-amended (control) produced the lowest suppression of J2 with a population of 71.6. Reproduction factor (RF) and gall index (GI) followed similar trend to the second stage juvenile (J2) population of suppression upon application of the organic materials. This present observation is in accord with the work conducted by [7] where their result indicates that growing sunn hemp as a cover crop and applying certain organic amendments can improve okra production and suppress root-knot nematodes, which are very damaging to okra plants. In an earlier research, the nematicidal activity of ammonia releasing organic amendments or ammonium hydroxide $\left(\mathrm{NH}_{4} \mathrm{OH}\right)$ was enhanced by adding nitrapyrin, which maintained the ammonia concentration in the soil for longer period [8]. However, nitrapyrin cannot be used in organic farms were organic soil amendments are used as fertilizers and for controlling nematode and soil-bone fungal diseases. Several medicinal and herbal plant, such as Menthaspicata, Artemisia annua, neem (Azadirachta indica) and karanja (Pongamia glabra), have been tested for their nitrification-inhibiting efficacy [9] [10]. In particular, karanja and neem extracts have been found to be relatively effective in inhibiting nitrification [9] [11]. In the present experiment neem is used as the nitrification inhibition agent.

The influence of the various organic amendments on the plant parasitic nematode was reflected in the decreased in population densities of Meloidogyne spp. at harvest as detected in similar study by [12]. The nematodes reproduction factor (RF) which is an indication of the relationship between initial (Pi) and final (Pf) nematodes population showed the mixture neem and cowdung produced the best nematodes suppression with an RF of 0.1 .

Table 2 showed the growth and yield parameters of okra namely shoot height, root length, dry shoot weight, dry root weight and pod (fruits) weight has affected by the various treatments, Neem applied at $11.5 \mathrm{~g}$, manure $100 \mathrm{~g}$, combination of neem and cow dung $111.5 \mathrm{~g}$ and carbofuran $1 \mathrm{~g}$ were significantly $(P<0.05)$ increase compare to control treatment. However manure exhibited significantly $(P<0.05)$. Highest mean shoot height of $42.4 \mathrm{~cm}$, were seen in synergy followed by chemical, $36.3 \mathrm{~cm}$ and combination of neem and cow dung manure $34.2 \mathrm{~cm}$ compared to control treatment which gave significantly $(P<0.05)$ the lowest mean shoot height. Other growth parameters follow a similar trend. A combination of neem and manure produce the highest okra yield of 2.4 ton per hectare (T/ha), followed by sole neem and manure that produced 1.9 and $1.4 \mathrm{~T} / \mathrm{ha}$ respectively compared with furadan that produced $2.0 \mathrm{~T} / \mathrm{ha}$. The control treatment produce the least yield $1.1 \mathrm{~T} / \mathrm{ha}$.

\section{Conclusion}

The effect produced by sole neem kernel powder, sole cow dung manure and mixture of neem and cow dung on control of Meloidogyne spp. on okra was established in this study. Results showed mixture of neem and cow dung produced the lowest population of second stage juvenile (J2) of Meloidogyne spp. in soil, with a concomitant highest okra yield of yield of 2.4 tons/hectre (T/ha). Sole application of neem and cow dung suppressed nematodes population but not as good as when the two are combined. Such combined practices show a significant potential for application in organic farming and sustainable agriculture systems in a tropical or subtropical region as alternative to synthetic chemical nematicide that is harmful to the environment, man and biodiversity. In addition, returning organic materials to the soil, especially agricultural wastes and agro-industrial by products, contributes to reducing the amount of waste to be treated, and to support environmental protection. This work has open room for further investigations into enhanced nematicidal effect of cowdung soil amendment by neem 
Table 2. Effect of neem kernel powder, cow dung manure and combination of neem kernel powder and cow dung manure on the growth and yield of okra.

\begin{tabular}{ccccccc}
\hline Treatment & Quantity & Shoot height & Root length & Dry root weight & Dry shoot weight & Yield \\
\hline Neem (N) & $11.5 \mathrm{~g}$ & $34.4 \mathrm{ab}$ & $14.9 \mathrm{ab}$ & $11.8 \mathrm{ab}$ & $5.0 \mathrm{c}$ & $1.9 \mathrm{c}$ \\
Manure & $1005 \mathrm{~g}$ & $42.4 \mathrm{a}$ & $15.5 \mathrm{ab}$ & $11.9 \mathrm{ab}$ & $5.3 \mathrm{~b}$ & $1.4 \mathrm{c}$ \\
$\mathrm{N}+\mathrm{M}$ & $111 \mathrm{~kg}$ & $35.2 \mathrm{~b}$ & $18.6 \mathrm{a}$ & $15.7 \mathrm{a}$ & $9.0 \mathrm{a}$ & $2.4 \mathrm{a}$ \\
Chemical & $1 \mathrm{~g}$ & $36.3 \mathrm{ab}$ & $14.5 \mathrm{ab}$ & $11.4 \mathrm{ab}$ & $3.0 \mathrm{c}$ & $2.0 \mathrm{~b}$ \\
Control & $0 \mathrm{~g}$ & $37.7 \mathrm{ab}$ & $11.4 \mathrm{c}$ & $9.0 \mathrm{~b}$ & 2.0c & $1.1 \mathrm{c}$ \\
\hline
\end{tabular}

Values are mean of three replications. Mean followed by same letter within each column are not significantly different $(p<0.05)$. According to Fisher Least Significant Different (LSD) Test.

(Azadirachta indica). It is recommended that further researcher should be carried out on different crops and different rates of cowdung and neem as soil amendments.

\section{References}

[1] Ihekoronye, A.I. and Ngoddy, P.O. (1985) Integrated Food Science and Technology for the Tropics, Tropical Fruits and Vegetables. Macmillan Education Ltd., London and Oxford, 306.

[2] Noling, J.W. (2010) Nematodes Management in Okra. http://edis.fas.ufl.edu/m/\#publication

[3] Judy, A.T., Fery, R.L. and Philip, D.D. (2012) Re-Evaluation of Okra Accessions Reportedly Resistant to Root Knot Nematodes. www.clemsom.edu./hort/

[4] Uzo, J.O. (1992) Hybrid Vigor and Gene Action of Two Qualitative Traits of Flavor Peppers in Nigeria. Scientia Horticulturae, 22, 321-326. http://dx.doi.org/10.1016/S0304-4238(84)80003-5

[5] Asiegbu. J.E. and Uzo, J.O. (1984) Yield and Yield Component Responses of Vegetable Crop to Farm Yard Manure Rate in the Presence of Organic Fertilizer on Onion and Okra. Abstract on Tropical Agric, 8, 98.

[6] Chindo, P.S. and Khan, F.A. (1985) Use of Cow Dung Manure in the Control of Meloidogyne spp. Affecting Okra. International Nematol Newsletter, 7.

[7] Wang, Q., Li, Y., Klassen, W. and Handoo, Z. (2007) Influence of Cover Crops and Soil Amendments on Okra (Abelmoschus esculentus L.) Production and Soil Nematodes. Renewable Agriculture and Food Systems, 22, 41-53. http://dx.doi.org/10.1017/S1742170507001585

[8] Oka, Y. and Pivonia, S. (2003) Use of Ammonia-Releasing Compounds for Control of the Root-Knot Nematode Meloidogyne javanica. Journal of Nematology, 4, 65-71. http://dx.doi.org/10.1163/156854102760082212

[9] Sahrawat, K.L. and Mukerjee, S.K. (1977) Nitrification Inhibitors. I. Studies with Karanjin, a Furanolflavonoid from Karanja (Pongamiaglogra) Seeds. Plant and Soil, 47, 27-36. http://dx.doi.org/10.1007/BF00010365

[10] Usha, K. and Patra, D.D. (2003) Medicinal and Aromatic Plant Materials as Nitrification Inhibitors for Augmenting Yield and Nitrogen Uptake of Japanese Mint (Mentha arvensis L. var. Piperascens). Bioresource Technology, 86, 267276. http://dx.doi.org/10.1016/S0960-8524(02)00143-8

[11] Gnanavelrajah, N. and Kumaragamae, D. (1999) Nitrogen Leaching Losses and Plant Response to Nitrogen Fertilizers as Influenced by Application of Neem (Azadirachta indica A. Juss) Materials. Tropical Agricultural Research, 11, 29 41.

[12] Koenning, S.R., Edmisten, K.L., Barker, K.R., Bowman, D.T. and Morrison, D.E. (2003) Effects of Rate and Time of Application of Poultry Litter on Hoplolaimus columbus on Cotton. Plant Disease, 87, 1244-1249. http://dx.doi.org/10.1094/PDIS.2003.87.10.1244 